\section{New Microscopy Bulletin Board}

Nestor Zaluzec and colleagues at Argonne National Laboratory have inaugurated a new Microscopy ListServer/MailReflector System as a centralized Internet address to facilitate rapid exchange of scientific and technical information on all phases of modern microscopy. This new Microscopy Server supplements ANLEMC (Argonne National Laboratory EM Center) eMail communications and the widely-used EMMPDL (Microscopy and Analysis Public Domain Library). This new system is not to be confused with the Microscopy Society of America's electronic bulletin board.

The Microscopy Server went on-line on October 1, 1993 with about 200 "subscribers" gleamed from the world wide ANLEMC eMail address file. The overseas response has been enthusiastic and impressive. To date the format has been largely a question and answer dialog on equipment and software purchases, technique troubles and references on many of the most important aspects of microscopy. The microscopy server topics have included scanning probe microscopies, SEM, HVEM, HREM, analytical microscopy and even positron annihilation. Most of the material has been of some to major interest to this reader but it does fill up your in-basket with 10-15 messages a day. In the future, the system will allow subscribers to restict their eMail traffic to topics of primary interest to them.

Subscription is free - to enroll send an eMail message to "LISTSERVER@ANLEMC.MSD.ANL.GOV" and in your message simply include the line "SUBSCRIBE MICROSCOPY user name@your .eMail. address". e.g. "SUBSCRIBE MICROSCOPY RMFISHER@U.WASHINGTON.EDU" To reverse the process, simply send "UNSUBSCRIBE etc."

The system will "read" this statement, understand your purpose and send you a startup message to confirm your address. At that point you will be in electronic touch with the whole wide world of microscopy

R. M. Fisher

University of Washington

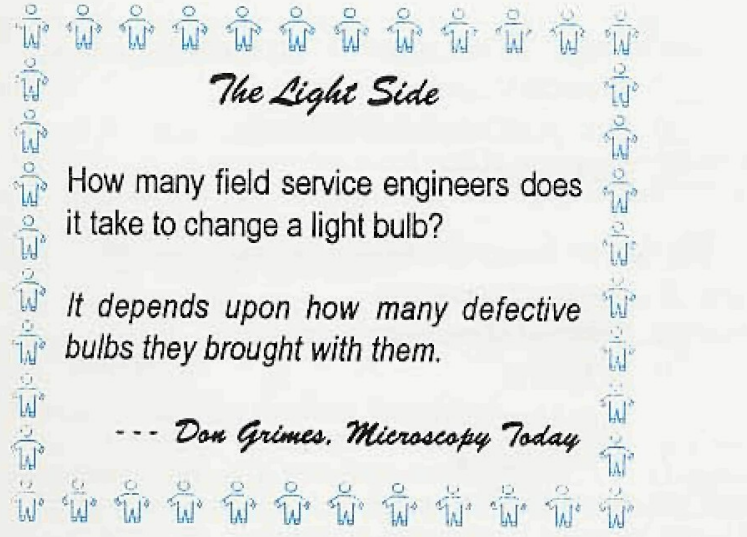

\section{SEM / TEM USERS:}

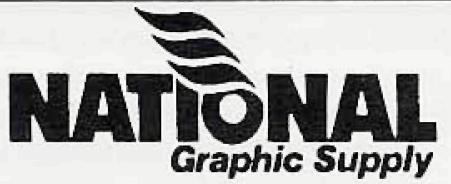

YOUR COMPLETE ELECTRON MICROSCOPY SUPPLIER

" KODAK, POLAROID, ILFORD \& FUJI FILMS

* KODAK, ILFORD, AGFA PAPERS \& CHEMICALS

- WIDE SELECTON OF SUNDRIES \& ACCESSORIES (KODAK SLFEVES, SAVAGE GLASSINE ENVELOPES. NEGATIVE FILES, \& VIEWING EQUIPMENT)

- SAME DAY SHIPMENT

- FRESH DATED PRODUCTS

- VERY COMPETITIVE PRICES

KODAK

ELECTRON MICROSCOPE FILM $4489 \&$ EL ECTRON IMAGE FILMSO163 $31 / 4^{*} \times 4^{*} 100 \& 250$ SHEETS * IN STOCK

(OTHER SIZES AVAILABLE)

CALL FOR A QUOTE ON

ALL YOUR PHOTOGRAPHIC NEEDS TODAY !!

\section{CALL GEORGE LAING OR BARBARA DEFRANCESCO \\ TOLL FREE AT 1-800-223-7130 \\ 226 NORTH ALLEN STREET \\ ALBANY, NY 12206}

FAX NUMBERS: OUTSIDE NYS (800) 832-2205 NYS (518) 438-0940 "SUBSTANTIAL SAVINGS ON NEW 250 SHEET MULTRPACK
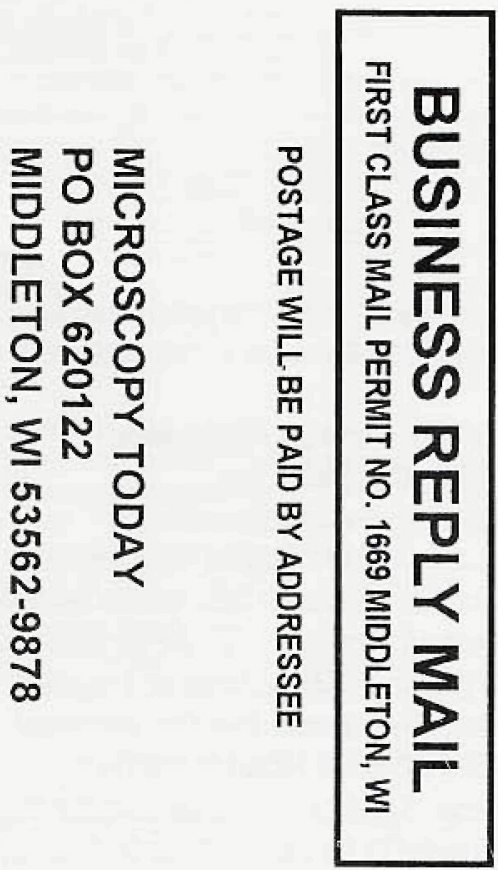